\title{
Vesicular changes in the myopathies of AIDS. Ultrastructural observations and their relationship to zidovudine treatment
}

Peter K Panegyres, John M Papadimitriou, Peter N Hollingsworth, John A Armstrong, Byron A Kakulas

\begin{abstract}
Six patients with AIDS and AIDS related complex (ARC) who developed neuromuscular symptoms associated with vesicular changes in muscle fibres are reported. Two patients in the advanced stages of AIDS, who did not receive zidovudine, developed proximal limb weakness and wasting: both had a necrotising myopathy with an unusual segmental vesicular change of myofibres. There were numerous vesicles 0.1 to $2 \mu \mathrm{m}$ in diameter produced by dilatations of the sarcoplasmic reticulum in fibres depleted of myofibrils. Four patients developed a myopathy while receiving zidovudine for AIDS. One of these had an inflammatory myopathy which showed the development of vesicular change due to enlargement and electron lucency of mitochondria. The three other patients with ARC developed muscle pains or weakness and elevated serum CK while on zidovudine. These patients also showed vesicular changes due to enlargement and electron lucency of mitochondria associated with disruption of sarcomeres and the presence of cytoplasmic bodies. The muscular symptoms resolved when zidovudine was stopped and repeat biopsy in one case revealed no abnormalities.
\end{abstract}

Central and peripheral nervous system complications are features of the acquired immune deficiency syndrome (AIDS). ${ }^{12}$ Disorders of voluntary muscle have also been described. Among these, inflammatory myopathy, ${ }^{34}$ inflammatory myopathy with giant cells, necrotising myopathy with minimal inflammatory infiltrate, ${ }^{67}$ myopathy with rod bodies, ${ }^{89}$ and type 2 fibre atrophy ${ }^{1011}$ have been recorded. Recently we described two AIDS patients who had myopathy characterised by vesicular changes by light microscopy-a rather unique myopathic reaction which occurred in the absence of zidovudine treatment. $^{12}$ In this study we present the ultrastructural findings of these two patients and four other AIDS patients who also developed vesicular changes in skeletal muscle while receiving zidovudine.

Materials and methods

Skeletal muscle for study from the right biceps brachii and quadriceps femoris was derived by local incision within 30 minutes after the death of patients 1 and 2 (see below). Permission for a general necropsy was refused in both. Muscle specimens were processed for paraffin embedded blocks, and formalin fixed frozen sections for ORO and PAS stains. Fibre typing was performed on paraffin sections using a monoclonal antibody to fast myosin (ICN products). The paraffin-embedded blocks were stained with haematoxylineosin, picro-mallory, Fite-Faraco, Methanamine silver, Giemsa, Gram, and Ziehl-Neelsen stains.

For electron microscopy the samples were fixed in $2.5 \%$ gluteraldehyde in phosphate buffer ( $\mathrm{pH} \mathrm{7.4)}$ for 16 hours. They were postfixed in $1 \%$ osmium tetroxide in phosphate buffer for one hour, then embedded in araldite. Sections were cut on an LKB ultramicrotome, stained with lead citrate and examined on a Philips 410 electron microscope. Normal control muscles and from HIV-Seronegative cachectic patients were collected under similar conditions and prepared in the same way. The muscle tissue was obtained by needled biopsy from vastus lateralis in patients 3 to 6 and processed immediately. The staining methods fibre typing and electron microscopy were performed as described above.

\section{Case histories and pathological findings}

Case 1

A 23 year old bisexual male, had a past history of rheumatic fever, psoriasis, and venereal warts. In November 1984 he developed lethargy, malaise, weight loss, and axillary lymphadenopathy. He was human immune deficiency virus (HIV) antibody positive by enzyme linked immunoabsorbent assay (ELISA). He developed oral candidiasis which was treated with nystatin. In September 1985 he suffered Pneumocystis carinii pneumonia which responded to intravenous Septrin. Ketoconazole was added to nystatin for the treatment of severe oral candidiasis. While an inpatient he developed Giardia lamblia enteritis which resolved with metronidazole. Multiple "cotton wool" spots were present in both retinae without papilloedema. These changes were ascribed to AIDS retinopathy. Cytomegalovirus serology and viral urine cultures were negative. The CD4 count was $240 \times 10^{9} / 1$ (ratio CD4/CD8 0.3$0 \cdot 4)$. In December 1985 he was investigated 
Figure 1 A myofibre with vesicular change associated with internal nuclei. Arrows indicate some vesicles.

$(H \mathcal{E} E \times 1624)$

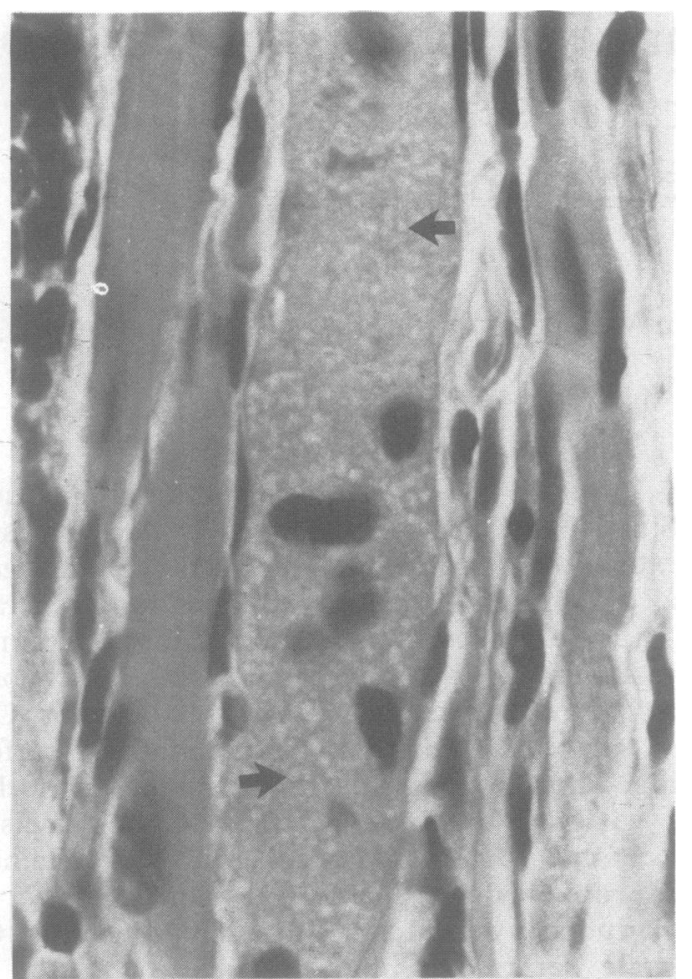

for headache. Neurological examination was normal and his weight was $62 \mathrm{~kg}$. A cerebral CT scan was normal. A lumbar puncture showed clear CSF with two white cells/ microlitre, 315 red cells/microlitre, protein $0.31 \mathrm{~g} / 1$, glucose $3.4 \mathrm{mmol} / \mathrm{l}$, and negative cryptococcal antigen. CSF cultures were negative.

Lymph node biopsy in January 1986 revealed follicular involution and Langerhans and monocytoid cell infiltrates, a pattern typical of the lymphoid depletion stage of HIV related lymphadenopathy. Pneumocystis carinii pneumonia recurred in May 1986 and it again responded to intravenous Septrin. In June 1986 he was febrile and his weight had

Figure 2 A myofibre showing numerous membrane bound vesicles, loss of sarcomeres, remnants of $Z$ bands, central nuclei, and lipofuscin pigment $(E M \times 9100)$. Inset: High magnification of a triad showing the dilated lateral sacs

$(E M \times 35000)$.

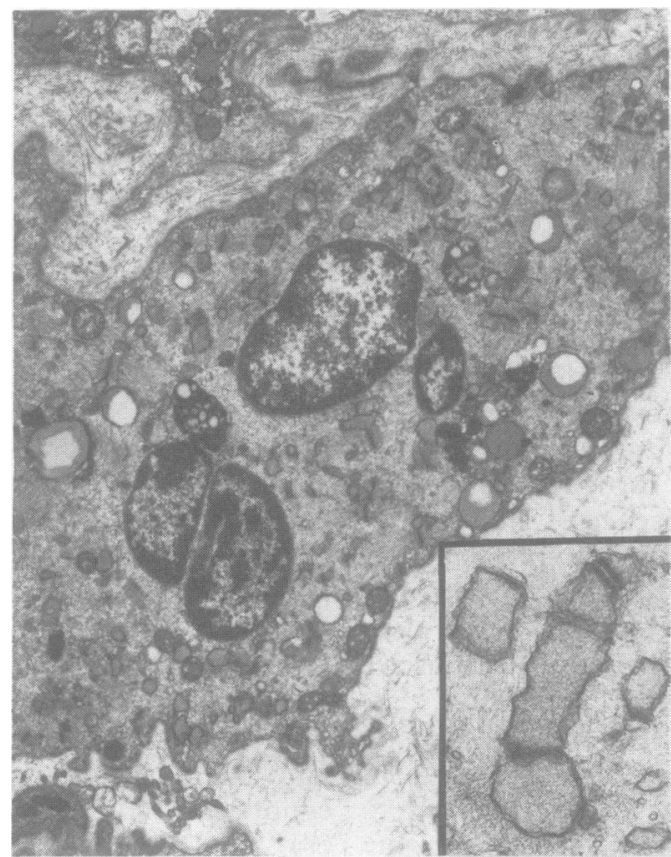

dropped to $59 \mathrm{~kg}$. Acyclovir was introduced and after 12 hours he was afebrile. In August 1986 Mycobacterium intracellulare was isolated from his faeces. His weight was now $49 \mathrm{~kg}$. In December 1986 he developed diarrhoea and immobility. He had received isoniazid, ethambutol, clofazamine and ansamycin over the preceding three weeks. He was now cachectic, weighing $37.4 \mathrm{~kg}$. There was proximal muscular weakness disproportionate to his cachexia. Muscle power was $3 / 5$ in the proximal shoulder and pelvic girdles. Neck flexors were $2 / 5$ and neck extensors $3 / 5$. The spleen was enlarged. The haemoglobin was $27 \mathrm{~g} / 1$ and he was transfused. The creatine kinase was 20 units/1 (normal <200). His condition deteriorated and he died on 7 January 1987 . He did not receive zidovudine.

\section{Light Microscopy}

The right biceps and quadriceps muscles were sampled. Both showed excessive variation in fibre size with small angulated fibres of both histochemical fibre types. There was no fibre type grouping in the right biceps, $58 \%$ of fibres were type 2 and $42 \%$ type 1 . The mean (SD) type 2 fibre size was 15 (3) $\mu \mathrm{m}$ and type $129(7) \mu \mathrm{m}$. The right quadriceps also showed no fibre type grouping. In this muscle $42^{\circ} \%$ of fibres were type 2 and $58 \%$ type 1 . The mean (SD) type 2 fibre size was 24 (12) $\mu \mathrm{m}$ and type $133(10) \mu \mathrm{m}$. There was fibre splitting, segmental necrosis, myophagia, and regeneration in both muscles with a slight mononuclear infiltrate. There were long chains of central nuclei $(<10)$ in some fibres with prominent nucleoli. Some fibres were split. The fat, glycogen and connective tissue contents were normal. Stains for fungi and atypical mycobacteria were negative. Five to $10 \%$ of myofibres showed a segmental vesicular change in non-necrotic non-regenerating fibres (fig 1). The vesicles which did not contain fat or glycogen measured $0 \cdot 25$ $2 \mu \mathrm{m}$ in diameter and were clear pink in $\mathrm{H} \& \mathrm{E}$ stained sections.

\section{Electron Microscopy}

Electron microscopy (EM) showed the vesicular change corresponded to aggregates of dilated cisternae of the sarcoplasmic reticulum (fig 2). This was associated with myofibrillar depletion disintegration of sarcomeres, and centrally located nuclei. Some myofibres showed an almost complete loss of their myofibrillar apparatus while the centrally aggregated nuclei were characterised by much heterochromatin which had separated from the surrounding nuclear envelope. The mitochondria were generally within normal limits. Associated satellite cells were intact and apparently unaffected. No retroviral or other virus particles were found in the muscle tissue but typical cytoplasmic tubuloreticular inclusions were prominent in endothelial cells and in some lymphocytes.

Case 2

A 27 year old homosexual male had been admitted to a country hospital on the 31 
October 1986 because of intermittent abdominal pain, perianal ulceration, lymphadenopathy, and a cutaneous eruption of both axillae of three weeks duration. The abdominal pain resolved spontaneously. On 1 January 1987 he developed diarrhoea and had lost $20 \mathrm{~kg}$ in weight. Examination showed a cachectic male with seborrhoeic dermatitis over the face and axilla. He weighed $52 \mathrm{~kg}$. Discrete lymph nodes measured $0.5 \mathrm{~cm}$ in diameter were palpable in the axillae and inguinal regions. There were multiple painful perianal ulcers. HIV antibody was detected by ELISA and Western Blot. The CD4 count was $50 \times 10^{9} / 1, \mathrm{CD} 4 /$ CD8 ratio $0 \cdot 1$. Rectal biopsy revealed intramucosal cryptosporidiosis which was also demonstrated by gastric aspiration. Herpes simplex type 2 was demonstrated in a perianal ulcer. On the 11 February 1987 ketoconzazole and nystatin were started for severe oesophageal candidiasis. On the 17 February 1987 he developed fever and neck stiffness. Lumbar puncture showed clear CSF with no red cells and seven white cells per microlitre. The CSF protein was $0.36 \mathrm{~g} / 1$ and glucose $3.7 \mathrm{mmol} / 1$. Cryptococcus neoformans was cultured from the $\mathrm{CSF}$. He was started on amphotericin. He developed right lower lobe pneumonia. Staphylococcus aureas and Haemophilus influenzae were cultured from the sputum. Amoxycillin was added to the treatment regime. About this time he showed progressive immobility and weakness disproportionate to his physical deterioration. Muscle wasting was generalised but more pronounced in the proximal upper and lower limb groups. Muscle strength was 4/ 5 for neck flexor, shoulder and pelvic girdle groups. Distal muscle power was normal. The serum creatine kinase was $160 \mathrm{ul}$ (NL 200). His condition progressively deteriorated and death occurred on the 6 March 1987. He did not receive zidovudine.

\section{Light Microscopy}

The right quadriceps muscle showed atrophic fibres of both histochemical fibre types without grouping. There were $26 \%$ type 2 fibres and $74 \%$ type 1 fibres. The mean (SD) type 2 fibre size was $25(8) \mu \mathrm{m}$ and type $126(12) \mu \mathrm{m}$. There was occasional segmental necrosis of myofibres with myophagia. The fat, glycogen and connective tissue content was normal. There was minimal mononuclear inflammatory infiltrate. Approximately $20 \%$ of non-necrotic fibres showed segmental vesicular change characterised by numerous pink-clear vesicles by $\mathrm{H} \& \mathrm{E}$ measuring $0 \cdot 5-1 \mu \mathrm{m}$ in diameter and replacing the normal myofibrillary architecture. This change was associated with central nuclei. The vesicles did not contain fat or glycogen and were visible in both paraffin and frozen sections.

\section{Electron Microscopy}

The vesicles corresponded to dilatations of the terminal cisternae of the sarcoplasmic reticulum. The majority of vesicles contained a mildly osmophilic material but several were electron lucent. Some vesicles were adjacent to the $T$-tubules and were obviously dilated lateral sacs. Disruption of the myofilamentous architecture was found in association with these vesicles. Some mitochondria were swollen but were easily distinguishable from the dilated sarcoplasmic reticulum. Occasional myeloid bodies were identified. Many nuclei exhibited peripheral clumping of chromatin and prominent nucleoli. The fat and glycogen content was within normal limits. Atrophic fibres showed excessive folding of the sarcolemma and coalescence of nuclear membranes between dark shrunken nuclei. Virus particles were not identified.

\section{Case 3}

This was a 34 year old male homosexual with a history of perianal herpes. In June 1986 HIV antibodies were detected by the ELISA assay while he was asymptomatic. In August 1986 he developed generalised lymphadenopathy and CD4 count $280 \times 10^{9} / 1, \mathrm{CD} 4 / \mathrm{CD} 8$ ratio $0 \cdot 2-$ 0.3 . He had Pneumocystis carinii pneumonia in July 1987 which responded to intravenous Septrin. He was thereafter maintained on Fansidar (sulphadoxine and pyrimethamine). Zidovudine $1200 \mathrm{mg}$ daily was introduced in September, 1987. Atypical mycobacteria were isolated from bronchial washings in October 1987 and isoniazid, rifampicin, and pyridoxine were started. Anti-tuberculous treatment was withdrawn in December 1987. In February 1988 he developed progressive muscular weakness. On examination there was generalised muscle wasting and weakness, most marked in the neck and proximal limb muscles. His weight was $62.9 \mathrm{~kg}$. The creatine kinase was $468 \mathrm{u} / 1$ (normal <200). He developed dysphagia due to candida in March 1988. He was started on ketaconazole but this was changed to amphotericin lozenges after one month. His muscular weakness persisted and in April 1988 the $C K$ was $773 \mathrm{u} / 1$. The zidovudine was stopped in April after a muscle biopsy showed an inflammatory myopathy (described below). His muscular weakness further progressed with difficulty in walking. In July 1988 his weight was $59.3 \mathrm{~kg}$ and CK was $740 \mathrm{u} / \mathrm{l}$. A second muscle biopsy was performed. Zidovudine was reintroduced in August 1988 and there was slight improvement in his muscle power. From September to December 1988 his muscle power deteriorated. The $\mathrm{CK}$ was now $1178 \mathrm{u} / \mathrm{l}$. His weight was $50 \mathrm{~kg}$ and a third muscle biopsy was performed.

\section{Light Microscopy}

The first biopsy of the right vastus lateralis performed in April 1988 showed a polyfocal mononuclear infiltrate with necrosis, myophagia and regeneration. Some small angulated fibres were found. There were $57 \%$ type 2 fibres and $43 \%$ type 1 fibres. The mean (SD) type 2 fibre diameter was 43 (11) $\mu \mathrm{m}$ and for type 1 fibres $54(11) \mu \mathrm{m}$. The second biopsy was from the left vastus lateralis taken in July 1988. It also showed a polyfocal mononuclear infiltrate with myophagia and regeneration. Split fibres and some small angulated fibres were present. There were $42 \%$ type 2 fibres and $58 \%$ type 1 fibres. The mean (SD) type 2 
Figure 3. Three myofibres with vesicular changes of sarcoplasm and loss of striations are shown at the right of the figure. Normal

myofibres are also seen
$(S)$. $(H \& E \times 691)$.

Figure 4 Case 3: portion of a myofibre displaying several enlarged mitochondria. Note the increased number of cristae mitochondriales,

vesiculation and presence of electron dense bodies on the inner chamber

$(E M \times 28000)$. Inset:

Mitochondrion showing a whorled arrangement of its cristae $(E M \times 24000)$.

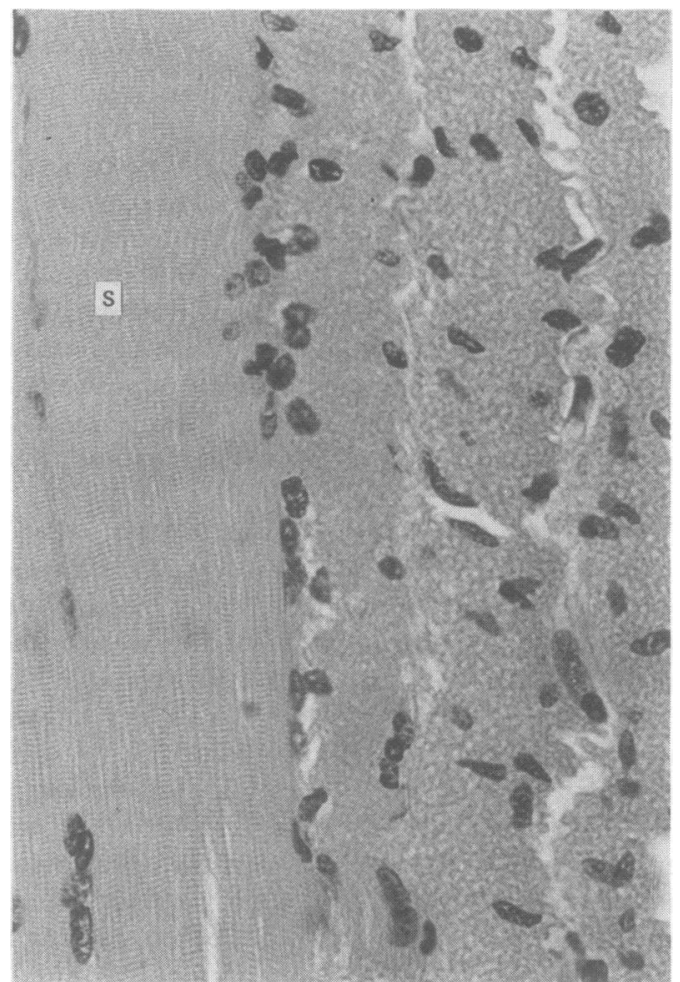

fibre diameter was 19 (6) $\mu \mathrm{m}$ and type 124 (5) $\mu \mathrm{m}$. Approximately $5 \%$ of non-regenerating, non-necrotic fibres showed segmental vesicular change characterised by pink-clear vesicles by $\mathrm{H} \& \mathrm{E}$ ranging in size from 0.2 to $1 \mu \mathrm{m}$. This change was not found on review of the first biopsy. Microvesicular change replaced the normal myofibrillary architecture in many fibres. The vesicles did not contain fat or glycogen. The third muscle biopsy in December 1988 showed persistence of the inflammatory myopathy and the microvesicular degeneration was more fully developed affecting $10-20 \%$ of fibres (fig 3 ).

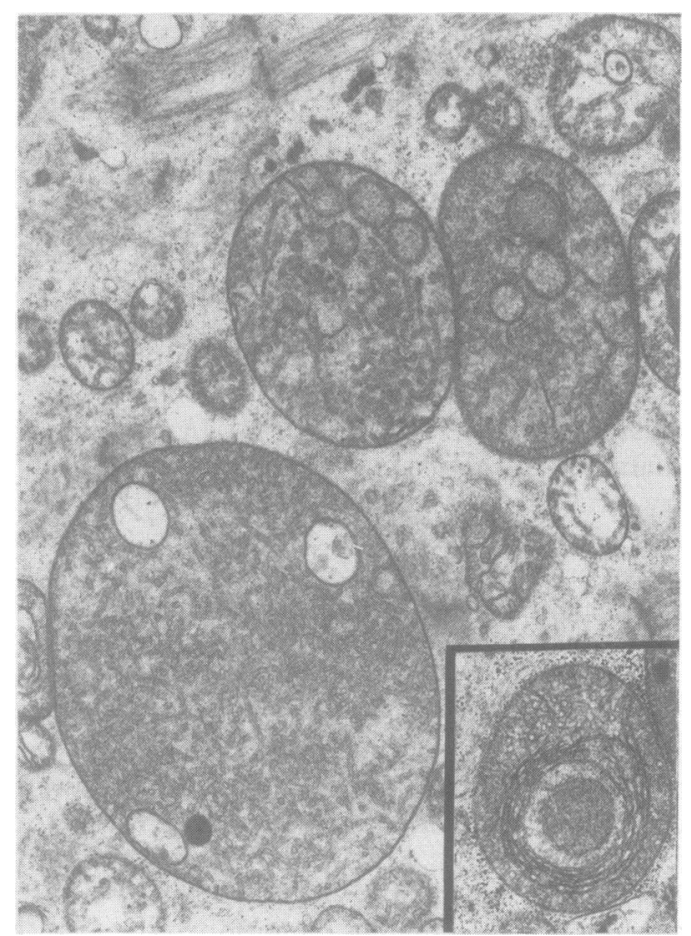

There were 39\% type 2 fibres and $61 \%$ type 1 . The mean (SD) type 2 fibre diameter was 16 (10) $\mu \mathrm{m}$ and type $130(8) \mu \mathrm{m}$.

\section{Electron Microscopy}

Ultrastructure of the first biopsy showed a patchy loss of myofibrils with irregularities of $\mathrm{Z}$ and I bands. Several cytoplasmic bodies were identified adjacent to aggregates of swollen mitochondria. The muscle nuclei, sarcolemma, and sarcoplasmic reticulum were normal. Virus particles were not found. The second biopsy showed in several fibres the accumulation of abnormal enlarged (5-7 $\mu \mathrm{m})$ mitochondria which possessed numerous cristae which on occasions were concentrically arranged. In addition myofibrillary disorganisation and increase in the number of lipid globules were also seen in such fibres. Many mitochondria of near normal size had distorted cristae, vesicles and electron dense deposits in their inner chamber (fig 4). Other myofibres showed minicores, cytoplasmic bodies, and excess lipid globules. The sarcoplasmic reticulum was normal. The third biopsy showed similar mitochondrial abnormalities associated with myofibrillary disorganisation, cytoplasmic bodies, and $\mathrm{Z}$ band streaming.

\section{Case 4}

A 52 year old male homosexual, HIV antibody positive by ELISA and Western blot since 1982. He developed generalised lymphadenopathy in 1984 and lymph node biopsy showed follicular hyperplasia with HIV-type retrovirus particles demonstrated ultrastructurally in the expanded dendritic cell labyrinths. His CD4 count was $320 \times 10^{9} / 1$ and CD4/ CD8 ratio was $0 \cdot 5$. Zidovudine $1 \cdot 2 \mathrm{~g}$ /day was started February 1988. He has received no other medications. Over the four months before November 1988 he experienced "aches and stiffness" in his thighs and legs when standing from a low chair and walking. His CK in January 1988 was $193 \mathrm{u} / 1$ (NL 200) and his weight $87 \cdot 2 \mathrm{~kg}$. In September 1988 the CK was $448 \mathrm{u} / \mathrm{l}$ and body weight $88 \mathrm{~kg}$. The zidovudine was ceased in November 1988. After two weeks there was improvement in the thigh symptoms. After four weeks he was asymptomatic with a normal CK (170 u/l).

\section{Light Microscopy}

Muscle biopsy in November 1988 of the vastus lateralis showed slight variation in fibre size with occasional small angulated fibres. Less than $5 \%$ of fibres showed vesicular change associated with central nuclei. These vesicles measured approximately $1 \mu \mathrm{m}$ in diameter and did not contain fat or glycogen. There was no necrosis, inflammation or group atrophy. There were $78 \%$ type 1 fibres and $22 \%$ type 2 . The mean (SD) fibre diameter of type 1 fibres was 37 (6) $\mu \mathrm{m}$ and type 236 (13) $\mu \mathrm{m}$. Repeat biopsy in January 1988 was normal.

Electron Microscopy

In a minority of fibres, mitochondria were enlarged and showed increased numbers of 
cristae, some of which were arranged in whorls or networks rather than the usual parallel array. The sarcomeres and nuclei were normal. No viral particles were identified. Mitochondria were normal in the repeat biopsy.

\section{Case 5}

A 50 year old homosexual male with AIDS related complex since 1986 . His CD4 count was $350 \times 10^{9} / 1$ and $\mathrm{CD} 4 / \mathrm{CD} 8$ ratio 0.1 and antiHIV antibody positive by ELISA and Western blotting. He had syphilis treated with penicillin in 1974 and urogenital herpes in 1984. He had been on zidovudine $1.2 \mathrm{~g} / \mathrm{d}$ for 12 months and Fansidar for two years. In the three months before October 1988 he had lost approximately $7 \mathrm{~kg}$ in weight and for two months complained of muscle "pains" in the thighs. He had difficulty climbing stairs. The CK was $544 \mathrm{u} / 1$ in August 1988 and was $930 \mathrm{u} / 1$ in September 1988 (NL 200). In October 1988 slight wasting with tenderness of the quadriceps was noted. There was also wasting of the sternomastoids with neck flexion being $4 / 5$. Following withdrawal of zidovudine in October 1988 he recovered from his muscular weakness and by December 1988 the CK fell to $140 \mathrm{u} / 1$.

\section{Light Microscopy}

A biopsy from vastus lateralis showed slight variation in fibre size with internal nuclei in about $10 \%$ of fibres. Necrosis and myophagia were present. About $5 \%$ of fibres showed vesicles measuring $0.5-1 \mu \mathrm{m}$ in diameter. They were pink-clear by $\mathrm{H} \& \mathrm{E}$ and replaced the normal constituents. Eosinophilic intracyloplasmic inclusions were found in occasional fibres. There were 59\% type 2 fibres and $41 \%$ type 1 . The mean (SD) fibre diameter of type 2 fibres was 18 (5) $\mu \mathrm{m}$ and 27 (8) $\mu \mathrm{m}$ for type 1 .

\section{Electron Microscopy}

Many fibres showed derangement of myofilaments, enlarged mitochondria ( 1 to $7 \mu \mathrm{m}$ ), cytoplasmic bodies, and central nuclei with prominent nucleoli. The mitochondria showed increased numbers of cristae, many of which lacked the normal pattern of parallel organisation, whilst others were arranged in concentric "whorls". In a few electron dense bodies were seen within the inner chamber.

\section{Case 6}

A 46 year old merchant seaman contracted HIV infection after a blood transfusion in July 1987. Three months later he developed fever and lymphadenopathy. He was HIV antibody positive by ELISA and Western blotting. $\mathrm{He}$ was anergic and had a CD4 count of $150 \times 10^{9} / 1$ and $\mathrm{CD} 4$ to $\mathrm{CD} 8$ ratio 0.3 . Zidovudine $1.2 \mathrm{~g} /$ day was started in December 1987. He has been asymptomatic and has had no opportunistic infections. In October 1988 he developed lethargy, $10 \mathrm{~kg}$ weight loss, and the loss of proximal limb muscle bulk. He experienced "aching" in his hamstring muscles after exercise. He was on spironolactone $50 \mathrm{mg} /$ day for portal hypertension and oedema secondary to alcoholic cirrhosis. Examination showed ascites and hepatosplenomegaly. His weight in November 1988 was $59 \mathrm{~kg}(82.4 \mathrm{~kg}$ in June 1988) and CK 613 u/1 (NL 200). Following withdrawal of the zidovudine muscular symptoms resolved and the $\mathrm{CK}$ fell to $155 \mathrm{u} / \mathrm{l}$ in January 1989.

\section{Light Microscopy}

Biopsy free vastus lateralis showed slight variation in fibre size with occasional atrophic fibres. There was no myophagia, regeneration, or inflammation. Less than $5 \%$ of fibres showed vesicular change with vesicles $1-2 \mu \mathrm{m}$ in diameter. The vesicles did not contain fat or glycogen and were identical to those found in the previous cases. There were $55 \%$ type 2 fibres and $45 \%$ type 1 . The mean (SD) type 2 fibre size was $33(8) \mu \mathrm{m}$ and type $133(8) \mu \mathrm{m}$.

\section{Electron Microscopy}

There were aggregates of enlarged mitochondria measuring 0.1 to $1.2 \mu \mathrm{m}$ in diameter in the subsarcolemmal regions. Many of the mitochondria had lost the normal linear arrangement of cristae. Instead, the cristae were arranged in a whorled pattern. Some of the cristae had electron lucent spaces which were single, multiple, or replaced most of the mitochondria. Prominent foci of $\mathrm{Z}$ band streaming were found in a single fibre in which the mitochondrial change and myofibrillary loss was most prominent.

\section{Discussion}

The table summarises the clinical and pathological data of the six patients. Patients 1 and 2 developed a clinical syndrome or proximal muscle weakness with a normal creatine kinase in the absence of zidovudine treatment. Light microscopy shows vesicular changes in the muscle fibres which ultrastructurally are dilated cisternae of the sarcoplasmic reticulum. Patients 3 to 6 had symptoms ranging from proximal muscle weakness to muscle pains associated with elevations of the creatine kinase in the presence of zidovudine treatment. Light microscopy also showed vesicular changes which ultrastructurally are enlarged, electron lucent mitochondria with circular or "whorl" cristae formations. Although vacuolation and disruption of a mitochondria are not infrequent artifacts the changes found here seem to us to be convincing especially the abnormalities of the cristae. It is noteworthy that the abnormal mitochondria and vesicles occurred only in fibres showing other evidence of injury.

Our findings in patients 1 and 2 suggest a distinct myopathological reaction in AIDS. Dilatations of the sarcoplasmic reticulum (SR) are not considered a result of autolysis (muscle specimens were collected within $\mathbf{3 0}$ minutes of death). We have not observed such changes in postmortem muscle. In addition cell membranes were not disrupted and mitochondria were generally well preserved unlike the changes seen in autolysis. Moreover, control muscle from cachectic patients without AIDS was examined under similar conditions and showed atrophic fibres without the vesicular changes recorded here. Tomlinson et al in 1969 studied 
Table Clinical and pathological data of patients with vesicular changes of skeletal muscle in AIDS

\begin{tabular}{|c|c|c|c|c|c|c|c|c|c|c|}
\hline \multirow[b]{2}{*}{ Case } & \multirow[b]{2}{*}{ Symptoms } & \multirow[b]{2}{*}{$\begin{array}{l}\text { Examination } \\
\text { findings }\end{array}$} & \multirow{2}{*}{$\begin{array}{l}\text { Serum } \\
\text { creatine kinase } \\
U \mid L \text { (Normal } \\
25-200)\end{array}$} & \multirow[b]{2}{*}{$\begin{array}{l}\text { Zido- } \\
\text { vudine } \\
\text { treat- } \\
\text { ment }\end{array}$} & \multicolumn{4}{|c|}{$L M$ findings $(+$ to ++++$)$} & \multirow[b]{2}{*}{ EM findings } & \multirow[b]{2}{*}{ Comment } \\
\hline & & & & & $\begin{array}{l}\text { Vesicular } \\
\text { change \% } \\
\text { fibres }\end{array}$ & Necrosis & Regen & Inflam & & \\
\hline $\begin{array}{l}1 \text { Male, } 23 \text { yrs } \\
\text { (B87/66A and } \\
\text { B87/66B) }\end{array}$ & $\begin{array}{l}\text { Proximal muscle } \\
\text { weakness }\end{array}$ & $\begin{array}{l}\text {-muscle wasting } \\
-3 / 5 \text { proximal } \\
\text { limb weakness }\end{array}$ & 20 & - & $+10 \%$ & + & + & \pm & $\begin{array}{l}\text { 1) Dilated } \\
\text { sarcoplasmic } \\
\text { reticulum } \\
\text { 2) Disintegration } \\
\text { of sarcomeres }\end{array}$ & \\
\hline $\begin{array}{l}2 \text { Male } 27 \text { years } \\
(\mathrm{X87/198)}\end{array}$ & $\begin{array}{l}\text { Proximal muscle } \\
\text { weakness }\end{array}$ & $\begin{array}{l}\text {-muscle wasting } \\
-4 / 5 \text { proximal } \\
\text { limb weakness }\end{array}$ & 168 & - & $++20-30 \%$ & + & + & - & $\begin{array}{l}\text { 1) Dilated } \\
\text { sarcoplasmic } \\
\text { reticulum } \\
\text { 2) Distintegration } \\
\text { of sarcomeres }\end{array}$ & \\
\hline $\begin{array}{l}3 \text { Male } 34 \text { yrs } \\
\text { February } 1988 \\
(\text { B88/355) }\end{array}$ & $\begin{array}{l}\text { Proximal muscle } \\
\text { weakness }\end{array}$ & $\begin{array}{l}\text {-muscle wasting } \\
-4 / 5 \text { proximal } \\
\text { weakness }\end{array}$ & 468 & + & - & ++ & ++ & ++ & $\begin{array}{l}\text { 1) Cytoplasmic } \\
\text { bodies } \\
\text { 2)Mitochondria } \\
\text { swollen }\end{array}$ & $\begin{array}{l}\text { zidovudine } \\
\text { ceased Feb. } \\
\text { '88 }\end{array}$ \\
\hline $\begin{array}{l}\text { July '88 (B88/ } \\
3662)\end{array}$ & $\begin{array}{l}\text { Deteriorating } \\
\text { muscle power }\end{array}$ & $\begin{array}{l}\text {-muscle wasting } \\
-3 / 5 \text { proximal }\end{array}$ & 740 & - & $+5 \%$ & ++ & ++ & +++ & $\begin{array}{l}\text { 1) Enlarged } \\
\text { electron lucent } \\
\text { mitochondria } \\
\text { with concentric } \\
\text { "whorl" cristae } \\
\text { 2) Cytoplasmic } \\
\text { bodies } \\
\text { 3) Disintegration } \\
\text { of sarcomeres }\end{array}$ & $\begin{array}{l}\text { zidovudine } \\
\text { recommenced } \\
\text { August ' } 88\end{array}$ \\
\hline $\begin{array}{l}\text { December } 1988 \\
(\mathrm{B88} / 6481)\end{array}$ & $\begin{array}{l}\text { Deteriorating } \\
\text { muscle power }\end{array}$ & $\begin{array}{l}\text {-muscle wasting } \\
-2 / 5 \text { proximal } \\
\text { limb weakness }\end{array}$ & 1178 & + & $++10-20 \%$ & ++ & ++ & +++ & $\begin{array}{l}\text { As for July ' } 88 \text {, } \\
\text { but changes more } \\
\text { severe }\end{array}$ & $\begin{array}{l}\text { zidovudine } \\
\text { ceased }\end{array}$ \\
\hline $\begin{array}{l}4 \text { Male } 52 \text { yrs } \\
(\mathrm{B} 88 / 5933)\end{array}$ & Muscle pains & -normal & 448 & + & $+5 \%$ & - & - & - & $\begin{array}{l}\text { Enlarged } \\
\text { mitochondria } \\
\text { with circular } \\
\text { cristae }\end{array}$ & $\begin{array}{l}\text { zidovudine } \\
\text { ceases }\end{array}$ \\
\hline (B89/60) & - & -normal & 170 & - & - & - & - & - & $\begin{array}{l}\text { Normal } \\
\text { mitochondria }\end{array}$ & $\begin{array}{l}2 \text { months after } \\
\text { last biopsy } \\
\text { and } \\
\text { withdrawal of } \\
\text { zidovudine }\end{array}$ \\
\hline $\begin{array}{l}5 \text { Male } 50 \text { yrs } \\
(\mathrm{B} 88 / 5329)\end{array}$ & Muscle pains & $\begin{array}{l}-4 / 5 \text { muscle } \\
\text { power }\end{array}$ & .930 & + & $+5 \%$ & - & - & - & $\begin{array}{l}\text { 1) Enlarged } \\
\text { electron lucent } \\
\text { mitochondria } \\
\text { with concentric } \\
\text { "whorl" cristae } \\
\text { 2) Cytoplasmic } \\
\text { bodies } \\
\text { 3) Sarcoma } \\
\text { disruption }\end{array}$ & $\begin{array}{l}\begin{array}{l}\text { zidovudine } \\
\text { ceased } 3 \\
\text { months later; }\end{array} \\
\text { CK } 140 \mathrm{u} / \mathrm{L} \\
\text { Muscle power } \\
5 / 5\end{array}$ \\
\hline $\begin{array}{l}6 \text { Male } 46 \text { yrs } \\
(B 88 / 6187)\end{array}$ & Muscle aching & 一normal & 613 & + & $+5 \%$ & - & - & - & $\begin{array}{l}\text { 1) Enlarged } \\
\text { mitochondria } \\
\text { with circular } \\
\text { cristae } \\
\text { 2) } Z \text { band } \\
\text { streaming }\end{array}$ & $\begin{array}{l}\text { zidovudine } \\
\text { ceased. } \\
\text { Muscle aching } \\
\text { resolved } 2 \\
\text { months later; } \\
\text { CK } 155 \mathrm{u} / \mathrm{L}\end{array}$ \\
\hline
\end{tabular}

the effects of cachexia upon the light microscopic appearance of skeletal muscle in 50 postmortem cases, none of whom showed the vesicular change described here. ${ }^{13}$ Ultrastructural studies of skeletal muscle from patients with cachexia and malnutrition have shown thinning of myofibrils and widening of the interfibrillary space, not abnormalities of the sarcoplasmic reticulum. ${ }^{14}{ }^{15}$ Patient 1 had diarrhoea but the electrolytes were normal. Even though patient 2 had mild potassium deficiency before the development of muscle symptoms, his potassium was normal at the onset and during muscle weakness. The amphotericin was stopped in patient 2 several days before the onset of muscle symptoms.

Patients 3 to 6 demonstrated mitochondrial abnormalities in the presence of zidovudine treatment and not alterations of sarcoplasmic reticulum. Patient 3 also had an inflammatory myopathy not seen in patients 4 to 6 . The first biopsy in patient 3 did not show vesicular change by light microscopy and ultrastructure revealed mild swelling of mitochrondria only while the patient was first receiving zidovudine. Zidovudine was stopped and five months later there was persisting inflammation and the development of vesicular change, which included enlarged electron lucent mitochondria with concentrically arranged cristae. These changes are attributed to the effect of zidovudine in a coexistent inflammatory myopathy, as the severity of vesicular change both by light and electron microscopy became poorer four months after the reintroduction of zidovudine. In patients 3 and 5 who had the most severe muscle weakness and greatest elevation of the creatine kinase, the mitochondrial abnormalities were accompanied by disruption of sarcomeres and cytoplasmic bodies. In patients 4 to 6 , who did not have a coexistent inflammatory myopathy, cessation of zidovudine resulted in resolution of the muscle symptoms and return of the creatine kinase to normal after two to three months. In patient 4 a repeat biopsy after the withdrawal of zidovudine showed no vesicular change and normal ultrastructure.

Our studies suggest zidovudine is a myotoxin and that it exerts its principal 
myopathic effect by disturbing mitochondrial structure and function. The abnormalities of mitochondria structure described here are similar to those recorded in the drug induced myopathies, namely chloroquine and emetine, where there is derangement of cristae and eventual mitochondrial disruption as we have found. ${ }^{16}$ Our studies confirm previous reports of a necrotising non-inflammatory myopathy associated with zidovudine treatment. ${ }^{1819}$ However, we believe vesicular change due to dilatations of the SR described above, is a distinct entity unrelated to zidovudine. In the presence of zidovudine, vesicular change in muscle fibres is due to vacuolation of mitochondria unrelated to the SR. Vacuolation of muscle has been described in AIDS in the presence and absence of zidovudine treatment. In the report by Stern et al 1987 the vacuolation measured $10-50 \mu \mathrm{m}$, and was centrally located within the myofibre. ${ }^{4}$ The vesicular changes as described by us were not found. Mitochondrial ultrastructural abnormalities were not reported in a patient who received zidovudine and developed vacuolation of muscle described by Gorard et al $1988 .{ }^{19}$ Vacuolation of voluntary muscle is recognised in the so called vacuolar myopathies and includes periodic paralyses, inclusion body myositis, lipid storage myopathies, glycogenoses, and the oculopharyngeal myopathies. ${ }^{20}$ The diagnoses were excluded clinically and pathologically. The vacuoles in these conditions measure $10-50 \mu \mathrm{m}$ in diameter unlike the $0 \cdot 1-2 \mu \mathrm{m}$ vesicles found in our cases.

In conclusion, we have described two distinct myopathological entities in AIDS. The first disorder occurs in the absence of zidovudine treatment, and is characterised by vesicular change by light microscopy due ultrastructurally to dilations of the sarcoplasmic reticulum and probably represents a unique cytopathic effect analogous to the "foamy degeneration" associated with other retroviruses. ${ }^{2122}$ The second entity occurs in the presence of zidovudine treatment and is also characterised by vesicular change by light microscopy but this change is due to enlargement and electron lucency of mitochondria which also show abnormal cristae. Zidovudine is a nucleoside analogue which inhibits the in vitro replication of human immunodeficiency virus and reduces the intracellular pool of pyrimidines ${ }^{23}$ which suggests that it may interfere with the homeostasis of mitochondrial DNA in muscle.
We thank Mrs Helen Rodgers for technical assistance with the electron microscopy and Mrs Dianne Johnston for typing. The work was supported by the Neuromuscular Foundation of Western Australia.

1 Snider WD, Simpson DM, Nielsen S, Gold JWM, Metroka CE, Posner JB. Neurological complications of acquired immune deficiency syndrome: analysis of 50 pateints. Ann immune deficiency synd

2 McArthur JC. Neurologic manifestations of AIDS. Medicine (Balt) 1987;66:407-37.

3 Dalakas MC, Pezeshkpour GH, Gravell M, Sever JL. Polymyositis associated with AIDS retrovirus. JAMA 1986;256:2381-83.

4 Stern R, Gold J, Dicarlo EF. Myopathy complicating the acquired immune deficiency syndrome. Muscle Nerve 1987;10:318-22.

5 Bailey RO, Turok DI, Jaufmann BP, Singh JK. Myositis and acquired immunodeficiency syndrome. Hum Pathol 1987;18:749-51.

6 Simpson DM, Bender AN. HTLV-III associated myopathy. Neurology 1987;37(Suppl 1):319.

7 Simpson DM, Bender AN. Human immunodeficiency virus-associated myopathy: Analysis of 11 patients. $A n n$ Neurol 1988;24:79-84.

8 Dalakas MC, Pezeshkpour GH, Flaherty M. Progressive nemaline (rod) myopathy associated with HIV infection. N Engl J Med 1987;317:1602-03.

9 Gonzales MF, Olney RK, So YT, Greco CM, McQuinn BA, Miller RG, DeArmond SJ. Subacute structural myopathy associated with human immunodeficiency virus infection. Arch Neurol 1988;45:585-87.

10 Dalakas MC, Pezeshkpour GH. Neuromuscular complications of AIDS: diagnosis and management. Muscle Nerve 1986;99(Suppl):92.

11 Dalakas MC, Pezeshkpour GH. Neuromuscular diseases associated with human immunodeficiency virus infection. Ann Neurol 1988;23 (suppl):S38-S48.

12 Panegyres PK, Tan N, Kakulas BA, Armstrong JA, Hollingsworth P. Necrotising myopathy and Zidovudine. Lancet 1988;7:1050-51.

13 Tomlinson BE, Walton JN, Rebeiz JJ. The effects of ageing and of cachexia upon skeletal muscle. J Neurol Sci 1969;9:321-46.

14 Roy S, Singh N, Deo MG, Ramalingaswami V. Ultrastructure of skeletal muscle and peripheral nerve in experimental protein deficiency and its correlation with nerve conduction studies. J Neurol Sci 1972;17:399-409.

15 Dastur DK, Daver SM, Manghani DK. Changes in muscle in human malnutrition; with an emphasis on the fine structure in protein-calorie malnutrition. In: Progress in Neuropathology. New York: Raven Press, 1979:4:299-318.

16 Bindoff L, Cullen MJ. Experimental (-) emetine myopathy. J Neurol Sci 1978;39:1-15.

17 Victor $M$. Toxic and nutritional myopathies. In: Engel AG, Banker BQ. Myology. New York: McGraw-Hill, 1986;2:1807-42.

18 Bessen LJ, Greene JB, Louie E, Seitzman P, Weinberg H. Severe polymyositis-like syndrome associated with zidovudine therapy of AIDS and ARC. $N$ Engl $J$ Med 1988;318:708.

19 Gorard DA, Henry K, Guiloff RK. Necrotising myopathy and zidovudine. Lancet 1988;7:1050.

20 Kakulas BA, Adams RD. Metabolic, endocrine and miscellaneous diseases. In: Kakulas BA, Adams RD, eds. Diseases of Muscle. Philadelphia: Harper and Row, Diseases of $1985: 612-68$.

21 Hooks JJ, Gibbs. CJ. The foamy viruses. Bacteriol Rev 1975;39:169-85.

22 Brown P, Nemo G, Gajdusek DC. Human foamy virus: further characterisation, seroepidemiology and relationship to chimpanzee foamy viruses. J Infect Dis 1978;137:421-27.

23 Furman PA, Fyfe JA, St Clair MH, Weinhold K, Rideout $\mathrm{JL}$, et al. Phosphorylation of 3'-azido-3'deoxythymidine and selective interaction of the 5'-triphosphate with human immunodeficiency virus reverse transcriptase. Proc Natl Acad Sci (USA) 1986;83:8333-37. 